\title{
Visual Aesthetics "Djarum Black Motodify" Branding in Urban Lifestyle a Case Study (Visual Methodology Approach)
}

\section{Andreas Slamet Widodo}

Fakultas Seni Rupa dan Desain, Universitas Sebelas Maret

J1. Ir. Sutami 36A Kentingan Surakarta, Indonesia

andre.dkvfsrd@staff.uns.ac.id

\begin{abstract}
This development of image brand (branding) conducted by Djarum corporate, its Djarum Black was held with the visual communication approach who made urban lifestyle. This was embodied in the form of advertising and the activity of the urban lifestyle, one of them are "Djarum Black Motodify" event. Based on these phenomena, then the researcher focused on visual aesthetic branding Djarum Black (media and event) which conceived Djarum Black urban lifestyle are aimed for consumers. This research using visual methodology approach to give a description and explain the structure of matter visual code or associated mark with the symbol of contemporary culture. A critical approach use visual methodology, which means that visual to be considered placed in the community, and how visual it will have an impact on a culture. This is the incident happened in the daily, because it often many matters relating to the media visual found that we shall not see a phenomenon that occurs well. When a strategy of promotion through the visual and event have overcome reality and duplicate themselves quickly and sporadic, then aesthetics has captured the world and eliminate reality. A consequence, various "life" reduced into symbols codification and abstraction of the promotion strategy.
\end{abstract}

Keywords: visual aesthetics, branding, lifestyle, visual methodology

\section{INTRODUCTION}

A company is inseparable from promotion activity in the attempt of improving its product to consumer, promotion is a part of marketing strategy to improve selling value in order to maintain the company's life stability. It is also related to creating the image built by company, for both the product's image and the company's. It is the image building in the attempt of creating brand that is called branding. Branding becomes an efficacious activity in the strategy of winning product completion in consumer market; it is conducted to make the image of product brand acceptable and penetrable to the consumers' mind. 
Visualize symbol and advertising in promoting Djarum Black as a sign of having considerable force, so that capable of engendering lifestyle in the group that Djarum Black "uniformed". The symbolic power namely the operation power mechanism behind a symbol. Symbol has the power to construct reality order to be able to drive people to trust, admitting, and put to them of the realities of someone, a group of people, or a nation (Bourdieu, 1991: 169-170).

In order to understanding the structure of culture of Djarum Black community as urban subculture, with construction of a branding reality through visual conducted by the Djarum company. This is a great interest to the study, because it contains value is implanted into a loyal to a symbol, which the symbol has a controversy associated with health regulation on smoking, the broadcast on tobacco advertising products, and on the smoking prohibition in public area. Therefore, can suspected that visual branding that Djarum this company did not only just bring the impact on the outcome of promotion and omnipresence course, but it leads to the formation cultural values' lifestyle on the urban development.

The phenomenon of the visual information and understood structure, in order to criticized associated with a brand power to a public consumer in this community. Visual branding strategy in the culture media including promotion advertising and event has great potential to convince public consumers, that Djarum Black brand have lifestyle urban "typical" not shared by another brand. Structure of the visual message handled and elaborated explicitly, whether the concept and the technical that message want to be delivered to be understood intent and its aims. Lifestyle, according to Piliang (2003) is how consumer human beings actualize themselves through life semiotics. Life semiotics is some sign and code manifested into time, money, and object. Urban means something that is city in nature either directly or indirectly, related to urbanization (the migration of population from village to city) (Setijowati (Ed), 2010: 101). Urban is essentially related to traditional and modernity issues. Urban community is identical with lifestyle industrialization and consumption, thereby cultivating the existence of "urban modern society".

In such the event activity, "Black Community" (Both BCC and BMC) brings about urban lifestyle corresponding to the product concept of Djarum Black brand. These visual media, event, and community creates 'new' image of Djarum Black product, so that the imaging attempt taken will result in "Black Community" (black car and motorcycle community) sub-culture intended to affect the Djarum Black-smoking consumer toward a "typical" Djarum Black urban lifestyle. 


\section{Phenomenon of Djarum Black Visual Aesthetics Issues}

The larger number of Djarum Black communities presupposes that the effect of Djarum Black brand is very strong in constructing a community loyal to that brand. It is inseparable from the role of promotion strategy in visual form (visual media and event) integrated into previously established community. Such the attempt serves as a media for the company to embed brand ideology related to Djarum Black-typical urban life style.

For more detail, the phenomenon of Djarum Black promotion strategy will be explained in Figure 1 below:

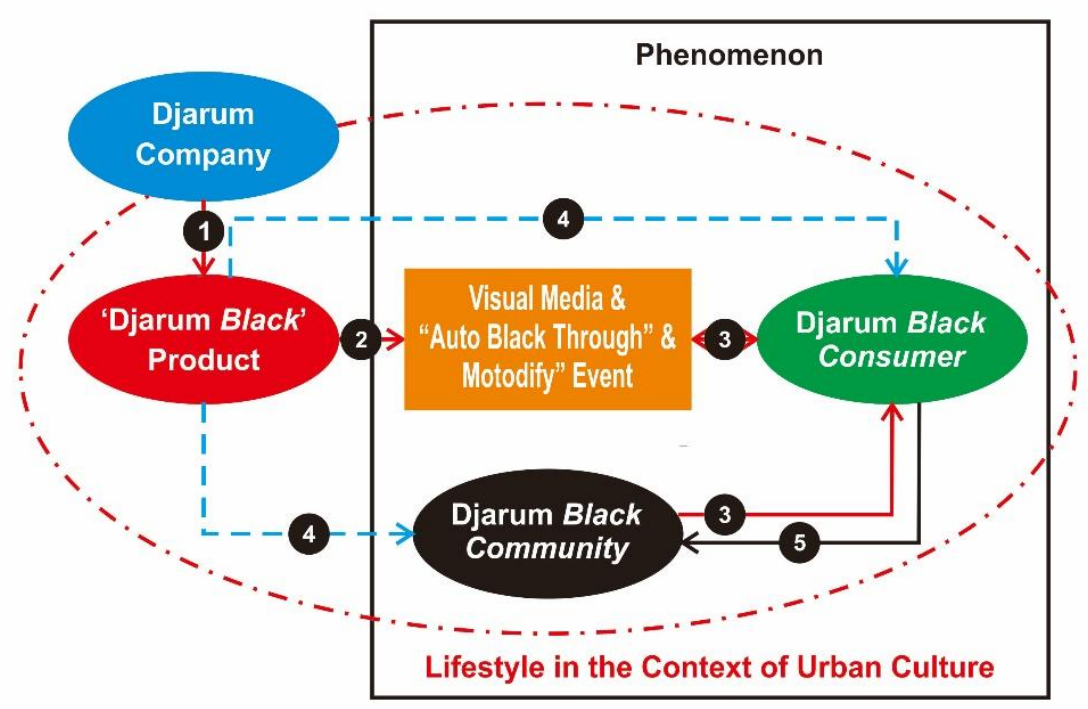

Figure 1. A Phenomenon of Djarum Black Promotion Strategy

Notes:

Djarum Company produces cigarettes through Djarum Black product division

Djarum Black Division designs visual strategy in the form of media and event of Djarum Black "Auto Black Through" and "Motodify".

Two-way interaction between visual media and Djarum Black "Auto Black Through" and "Motodify" event (as spectacle) and between Djarum Black community group and Djarum Black Consumers (as spectators), and interaction with Black Jarum community.

Djarum Company embeds brand ideology related to "typical” Djarum Black urban lifestyle, through visual media and Djarum Black event, and Djarum Black Community established previously.

Some of Djarum Black consumers having expectation on "typical” Djarum Black urban lifestyle will join Djarum Black community as the members. 
Considering the phenomenon, this research focused on the research on Djarum Black branding visual (visual media, event, and community) in bringing about on "typical" Djarum Black urban lifestyle intended to audience and consumer using Gillian Rose's Visual Methodology.

\section{METHOD}

\section{Research Paradigm}

Constructivism paradigm, according to Patton, is created based on ontological relativity in which it is explained that the reality is created dependent on how people view it, and no view is governed by empirical data (Patton, 2002: 92). This research paradigm considers how the social phenomenon develops in some of social context. Constructivism refers to the creation of individual meaning of relative knowledge on social context. The subject matter in this research is Djarum Black branding visual esthetics in the form of promotion through visual media and event as well as social phenomenon in the presence of some Djarum Black car and motor communities, in which the author attempt to understand informant, that is, creative division designs Djarum Black "Auto Black Through" and "Motodify" event in constructing Djarum Black promotion program through advertising media and event. This constructivism paradigm attempts to explain how a company, through its promotion strategy, constructs the reality like what the audience and consumer trust, believe, and understand as a "typical” Djarum Black urban lifestyle.

\section{Qualitative Research Method}

The main objective of qualitative method use was to capture the process of finding the meaning. What the qualitative researcher searches for in his research activity is how to conduct a research and how to interpret the result of research, all of which is dependent on theoretical study and approach used (Bogdan \& Taylor, 1993: 44-45).

Considering descriptive nature of research, the data collected constituted words, and figures rather than numbers. As such, this research report contains citations of data to give a description on the report presentation. The data was obtained from interview script, field note, photograph, videotape, personal document, note or memo, and other official document. It is in line with the objective to be achieved in this research, to emphasize more on the attempt of revealing visual meaning in imaging process in the visual esthetics of Djarum Black branding becoming the phenomenon within society, and expected to become a descriptive explanation. 


\section{Method of Collecting Data}

The primary data for this research was obtained from visual document of Djarum Black advertisement. In-depth interview with the community was conducted during the event combined with field observation. As Lincoln and Guba (1985) suggested, interview can construct concerning people, event, organization, feeling, motivation, demand, care, and etc.

Field observation was used because it could capture the social natural condition where behavior occurred, could capture the event affecting the social relation of participants and could identify regularity and repeated phenomenon in social life by comparing and considering the difference of data obtained from a study (Black dan Champion, 1992: 286). Such the combined method was used to obtain complete information, to minimize the incorrect information from informant. Data collection was ended when the data obtained had been saturated (Sugiyono, 2007: 23).

\section{Method of Analyzing Data}

Analysis process requires a disciplined study, creative insight and precise attention to evaluation objective. Analysis and interpretation conceptually are two separate processes. Analysis is the process showing how the data is organized, organizing what existing in a pattern, category and basic descriptive unit. Interpretation involves the attempt of including meaning and significance into analysis, giving descriptive pattern of explanation, and finding the relationship and the interrelationship between descriptive dimensions (Patton, 2002: 250).

This research began when the author had been sufficiently impressed with the presence of Djarum Black branding activity that could construct consumer into large-scale Djarum Black community, by means of branding activity supported with media publication. Having conducted observation on Djarum Black branding activity constituting (printed and electronic) advertisement media, event, and community, the author finally selected informants from one of Djarum Black communities.

This study employed case study strategy, so that all of data were obtained from the field/research site; the technique appropriate to this research was an interactive model of analysis (Miles \& Huberman, 2009). In this model, there are three components of analysis: data reduction, data display and conclusion drawing or verification. The activity was conducted in interactive form, even it had been conducted during data collection process. Then, the author moved between the three components of analysis: data reduction, data display and conclusion drawing/verification after data collection in this analysis process. 


\section{Analytical Framework of Djarum Black Visual Brand Aesthetics}

Considering research paradigm and data analysis technique above, in analyzing visual data, visual methodology was used. Visual data constituted visual media of Djarum Black event and audience existing in the event and audience affiliated with Djarum Black community. This methodology shows some criteria of critical approach to analyzing visual material. From some reading sources, there is a differentiation of terms vision and visuality. Vision is what can be seen psychologically by human eyes. Meanwhile visuality refers top how vision is constructed in various ways, how we see, how we can, are allowed to or are enabled to see, and how we see that the visible or the invisible one exists. Another phrase having similar connotation to visuality is scopic regime. Both of them refer to what is seen and how it is seen as something constructed culturally (Rose, 2001: 6).

This visual methodology interprets visual broadly including three components: the site(s) of the production of an image, the site of the image itself, and the site of the audience (ibid, 16). Visual analysis was conducted using the site of image itself in Gilian Rose's visual methodology, while composition modality analysis using analysis theories as an aid, that is Gunther Kress and Theo Van Leeuwen's Visual Grammar theory. This theory analyzes visual text on a media. Kress and van Leeuwen (2006) did not explicitly order the analysis step by step using their theory, but their theory will elaborate the important points to be considered during visual text analysis using Visual Grammar in detail.

In understanding and revealing the meaning of message contained in visual material in the visual branding of Djarum Black product, such product promotion used visual symbols with certain interpretation (meaning segmented for receiver/audience as communicant). In this contemporary visual work, in order to increase understanding when a text is released from the enacted code, post-structural semiotic theory is used. Sign becomes a myth produced and consumed by audience in visual message form in Djarum Black visual branding. As cited by Rose (2001: 91), myth is the form of ideology. Barthes (in Storey, 1993: 88) himself defines ideology as "... a body of ideas and practices which defend and actively promote the values and interests of the dominant groups in the society". The meaning of an ideology makes the public audiences participating in Djarum Black event forget that everthing must have been constructed. This meaning deconstruction is conducted with signification process that will make something apparently implicit formerly (ideology) explicit.

Considering the methods in this research, those methods were elaborated into one methodology to analyze visually, in revealing the meaning of Djarum Black visual brand esthetic phenomenon in bringing about "typical” Djarum Black urban lifestyle. This analytical theoretical framework is the description of visual analysis process the author conducts in obtaining visual meaning, as illustrated in Figure 2 below. 


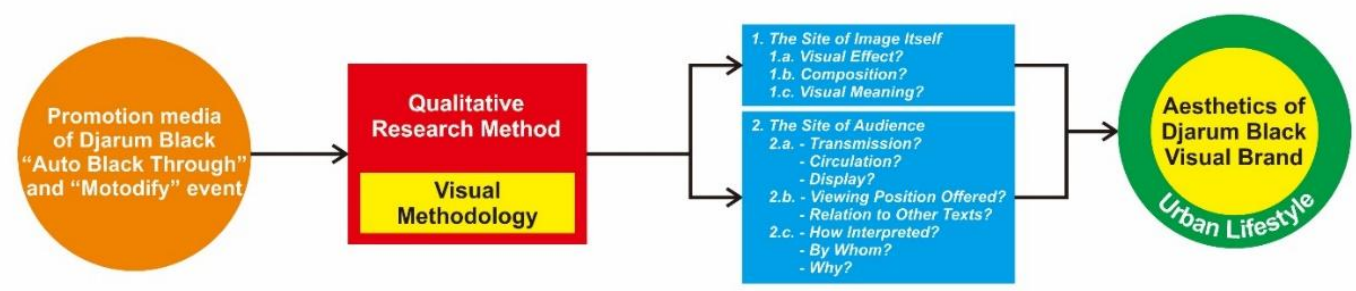

Figure 2. Analytical Framework of Djarum Black Visual Brand Aesthetics

\section{The Application of Visual Methodology Analysis (Gillian Rose's Visual Methodology)}

Considering the three sites in visual methodology, the author used two sites in interpreting visual: the site of the image itself and the site of the audience (see Figure 3). The reason of why the author chose those two sites is that the site of the image itself is applied in analyzing visual media and Djarum Black promotion event to find the meaning of esthetics existing in the media, while the site of the image itself is applied in analyzing Djarum Black community and audience in Djarum Black "Auto Black Through" and "Motodify" promotion event. The result of both analyses will be connected to its modality relation to reveal the meaning of Djarum Black visual brand in bringing about "typical” Djarum Black urban lifestyle.

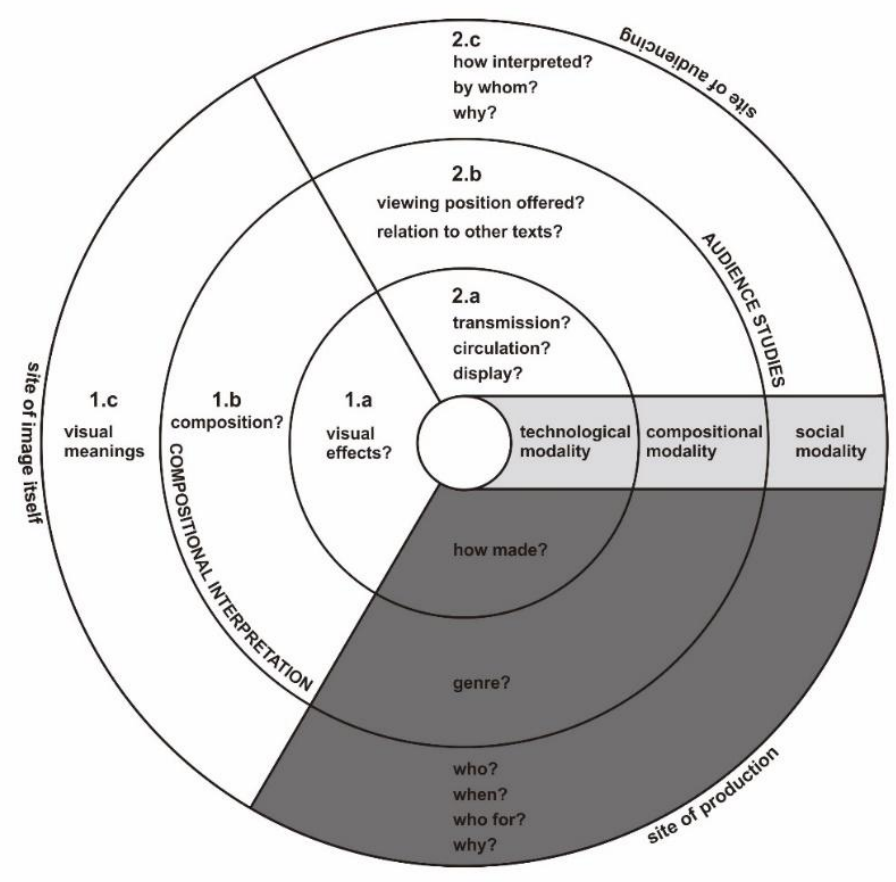

Figure 3. Visual Methodology (Gillian Rose, 2001: 30) selected in The site of the image itself and the site of the audience 
Systematically and constructively, this Visual Methodology (Gillian Rose) will analyze visually using a variety of theoretical framework and relevant methodology, thereby providing some matters concerning how, why, and when we can use visual technology to support research, or even to be the main component of research. In relation to cultural context, Rose's method emphasizes on five aspects: (1) Picture has special resistance and effect in using articulation, tended to be equipped with other (text) information; (2) Picture (figure) can create, solidify, weaken, and even destroy social relation and difference; (3) Picture (figure) has dynamic relationship with its spectators - how a picture is seen not only is dependent on the picture itself but also affects the audience's point of view; (4) Picture is technically related to context and location with different practice and rule; (5) just like picture having resistance, audiences (spectators) have different responses. This fifth aspect, according to Gillian Rose, is usually neglected, and generally reception study or audiencing existing only studies the visual relevant to mass media, in which mass media becomes visual cultural product to the society.

In this application of visual methodology, the author selected one of Djarum Black automotive event, that was, Djarum Black "Motodify". The media to be analyzed as visual material was billboard; this billboard was taken during the event organized in Solo on September 22-23, 2012. The data constituting picture on billboard was analyzed with theories using image base research:

Data collected was then analyzed using theoretical framework of visual methodology, visual meanings aspect through still image, by prioritizing the way of explaining its visual using the site of image itself, in which the author would analyze the visual based on image analysis unit, typo character, layout, color and text message considered as important thereby creating and representing the brand of Djarum Black.

The author would analyze visual data using visual grammar analysis approach. This visual grammar theory consists of three structures: Narrative, Representation, and Composition. In conducting analysis, one of those three structures was selected, that was, composition. This structure was used to help analyze Composition Interpretation in composition modality in visual methodology. In the composition structure of visual grammar, there are four components of its analysis instrument. They are: Spatial distribution, Salience, Framing, Color (Kress and Leeuwen, 2006: 210), these four components are intended to obtain the meaning of composition.

\section{RESULT}

In this visual analysis, the method was applied to the billboard media of Djarum Black "Motodify" Solo (See Figure 4). Such the media contains visual elements 
including visual identity of product, event logo, tagline, and illustration. Visual identity is different from logo; visual identity has a meaning more than logo does.

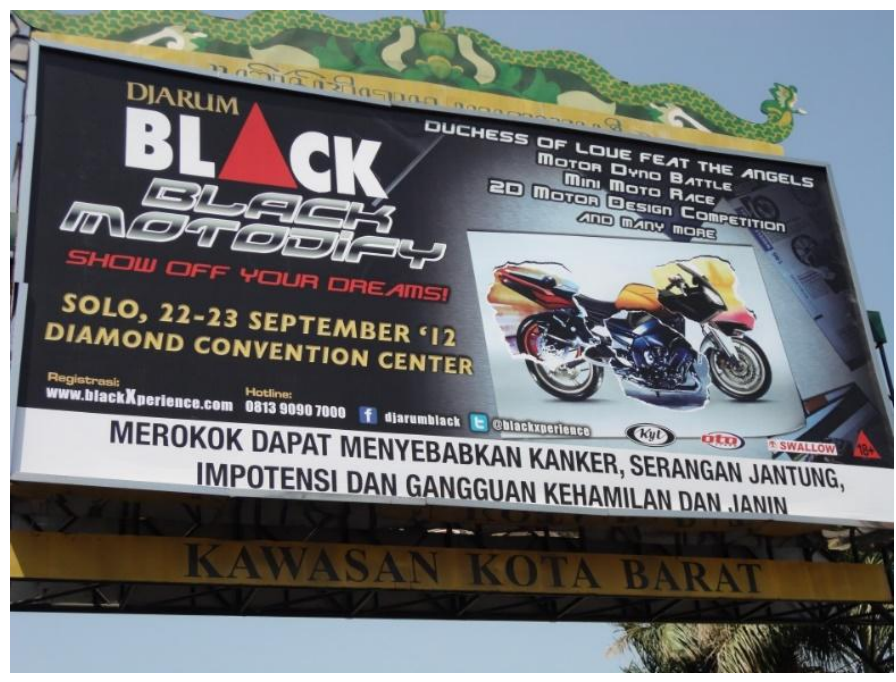

Figure 4. Billboard of Djarum Black "Motodify" Solo.

It can be stated that logo and identity of Djarum Black is an integral, interrelated and interdependent unit, and this visual identity is expected to provide perception to be delivered to consumer or audience. The perception constructed is that Djarum Black is a product produced by Djarum Company that organizes a large event of automotive modification. Billboard is one of mass media featuring visual identity of Djarum Black, thereby confirming that such the event is not an ordinary event but the exclusive one for motor modifier, in which the name of company become guarantee because PT. Djarum is a large company as the organizer.

In visual typography element, every letter in the text has its own personality. Selecting appropriate typography means selecting the letter character representing the image to be conveyed. Its selection can be initiated with selecting serif or san seriffont. Seriffont is often used to describe something related to tradition because its form character uses hook, while san seriffont is often used to describe something related to modernity because it tends to be upright, solid and without hook.

The logo of "Black Motodify" event along with tagline "Show off Your Dreams!" exerts an effect on audience through letter character with sans serif type in its futuristic-style visualization and delivers message persuasively. The character of letter in "Black Motodify" text is visualized using visual effect - through image processing software - glossy like stainless steel befallen with light, thereby giving technological impression adjusted with the theme of event about motor modification. Meanwhile the red-color letter in tagline "Show off Your Dreams!" gives different emphasis compared with other letter color. This tagline has persuasive message to attract the audience in order to be challenged in participating in 
the modification event. The position of tagline under the logo of "Black Motodify" event becomes one unit persuasively inviting the audience to show off their creativity and to make their dream come true to modify motor in this event.

In this billboard, there is body copy providing information about artist and some events to be held - Duchess of Love Feat. The Angels, Motor Dyno Battle, Mini Moto Race, 2D Motor Design Competition and Many More. The choice of same letter with that in tagline is made to feature the same characteristics using white color in order to be contrast with its background. In the presence of information through this body copy, audiences are offered to attend the event as participants or as the spectators only.

The illustration featured in the billboard of billboard Djarum Black "Black Motodify" as if shows a piece of paper with collaged motor picture (see Figure 5). The visual paper with motor picture is as if collaged with a piece of paper with other series-motor picture on cover head lamp, racing muffler, body cover, and alloy wheel. The image built in the visual message means that the idea modifying motor is same like playing collage game, that is, to replace the elements of motor corresponding to the modifier's want. Meanwhile, on the background there is illustration of motor spare part catalogue, the visual of which features alloy wheel picture. The visualization featured entirely as if represents a designer's work table in designing his/her motor modification.

This ostentation is called symptom by Jean Baudrillard. When the community can no longer distinguish the symptoms characterizing the actual sickness from those not so and the real from the counterfeit, these symptoms can be produced and no longer acceptable as original fact; therefore all of sicknesses become simulation. The symptom arising is ostensible sickness. "An individual ill ostensibly can go to bed easily and convinces that he is sick. An individual stimulating a sickness produces some symptoms inside of him" (Baudrillard, 1983).

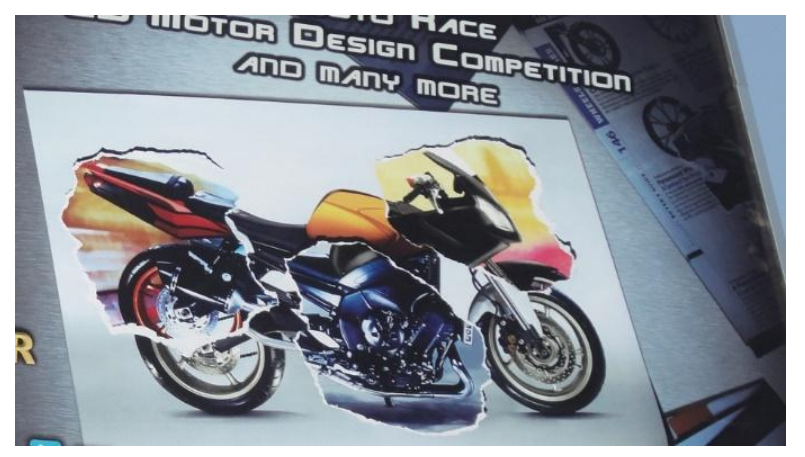

Figure 5. Illustration in billboard of Djarum Black "Motodify"

The representation of a designer's working table in designing motor modification on the billboard media of "Black Motodify" as the form of image signification. The image 
represented is the drawing of motor racing modification collage. This image characterizes a certain value, the development of creativity among urban youths. The meaning of image is explored by realizing that the image is produced in dynamic power and ideology (Sturken \& Cartwrigth, 2001).

Under tagline "Show Off Your Dreams!" there is a caption informing the location and time of "Black Motodify" event organization, with the text, Solo, 22-23 September '12 Diamond Convention Center". The letter chosen has good legibility, because it uses familiar sans serif font that is readable to the audiences. Letter size and yellow color provide different color appearance compared with other, so that the audience can catch the text visualization from about 50-meters distance. In legibility rule of outdoor design, particularly billboard, advertisement text should be readable in at least 50-m distance because when seeing the advertisement, audiences are in motion (riding actively on the street) and their reading duration is very short. The text featured will facilitate the audience to find out the location where the event is organized quickly.

Sequence (order of reading attention) on the billboard layout uses inversed $\mathrm{C}$ sequence (Oxfam). The sequence starts with logo Djarum Black, logo of "Black Motodify" event, tagline "Show off Your Dreams!" (One unity) $\rightarrow$ information of "Duchess of Love Feat. The Angels, Motor Dyno Battle, Mini Moto Race, 2D Motor Design Competition and Many More" events $\rightarrow$ illustration of motor collage and its background $\rightarrow$ location and time of event "Solo, 22-23 September '12 Diamond Convention Center" (See Figure 6). The Sequence of reading is adjusted with a local community's habit, in Indonesia, reading starts from the left to the right or from the top to the bottom (Rustan, 2009).

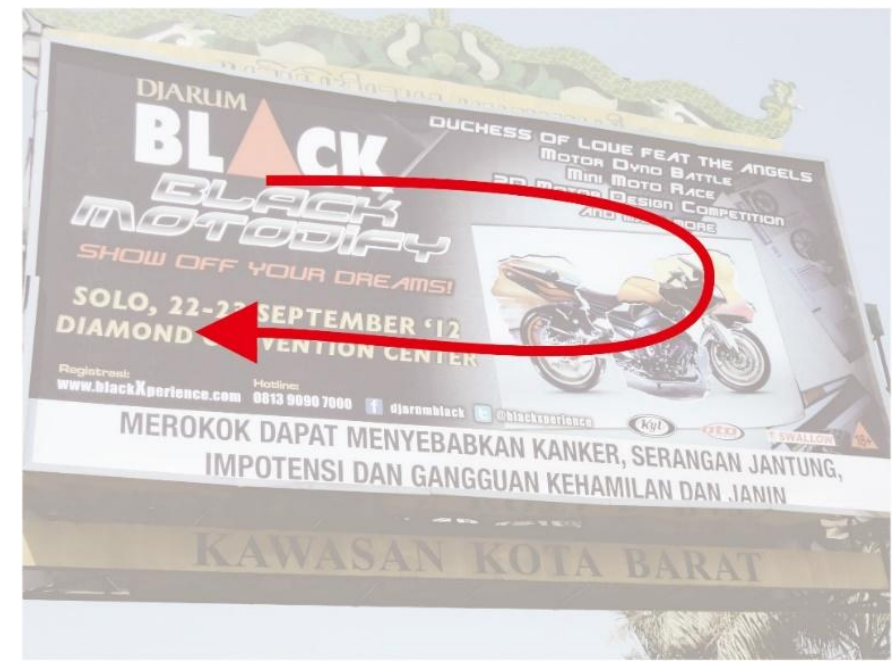

Figure 6. Sequence of Djarum Black "Motodify" layout billboard

Below information on location and time of event organization there is a baseline providing information with the sequence from the left to the right, containing Registration 
(participant registration) that can be accessed in www. blackxperience.com, with Hotline service on Phone Number 081390907000 and in social media Facebook djarumblack and Twitter@blackxperience. Under the illustration, there are logos of sponsors such has KYT helmet, OTO Trend magazine, and SWALLOW tire, and red triangle logo with 18+number indicating that this cigarette is normatively prohibited to be smoked by those less than 18 years old. All of information related to the participation in the event is featured on the billboard, thereby offering the audience to access the event through those media. On the bottom there is disclaimer obligatorily included as the government's appeal, recalling that this promotion product is cigarette, "merokok dapat menyebabkan kanker, serangan jantung, impotensi dan gangguan kehamilan dan janin (smoking cigarette may cause cancer, heart attack, impotency, and pregnancy and fetal disorder)".

Visual color in the billboard gives meaning or perception in its visual. Overall, the color of billboard is dominated with black. Black color is basic color used in the billboard, while the color of respective letters serves as contrast only to make the text readable. In logo Djarum Black the color of identity is gold on text Djarum, white on BLACK word and red on triangle symbol (see Figure 7). Thus, it becomes the meaning of company identity and its product, Djarum Black. Connotatively, black red symbolizes power, technology and elegance, so that it can be said that the concept of color can build the image of Djarum Company's power. As a large company with power, Djarum has power to control and to distribute its media. Foucault stated that in the present era enlivened with science and technology development, power is no longer a subjugating institution, structure or strength. Power is not owned, does not own, but it is a complex relation dispersed and present everywhere (Foucault, 1977).

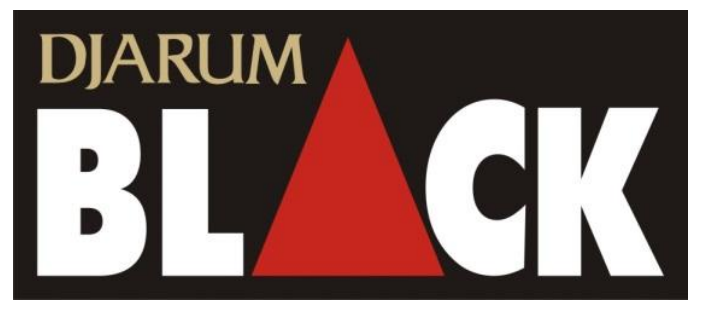

Figure 7. Logo of Djarum Black

The aesthetics of Djarum Black's visual brand in the advertisement media of Djarum Black "Motodify" featuring the signification of motor modification image persuade the audiences effectively, thereby contributing considerably to the involvement of audience, particularly the modifier in this event. Every event is always full of audiences, including participants of modification contest or model photography, Djarum Black communities and visitors who watch the event or Djarum Black merchandise hunter. 
In Djarum Black "Motodify" event packaged glamorously in such a way that the event becomes an abstract space constructed for the audiences to satisfy the passion of automotive lovers, particularly the modified motor lovers. Abstract space is the space that has encountered politicization and bureaucratization, so it produces and encourages social homogeneity (See Figures 8, 9, 10, 11). Henri Lefebvre (1991: 26-27) stated that "Abstract Space is a social product. It is not merely a neutral space filled in arbitrarily, but the dynamic one constructed by those having control and domination or power". This space becomes a media dominated by a large company's power, Djarum's. Thus promotion media in Djarum Black brand shifts from merely reflecting reality to being a mask and reality diversion all at once. When Djarum Black brand changes into a new reality in the form of urban lifestyle, at that time everything changes into esthetic reality. "Art has today totally penetrated reality... the aestheticization of the world is complete". (Baudrillard in Leach, 1999: 5-6).
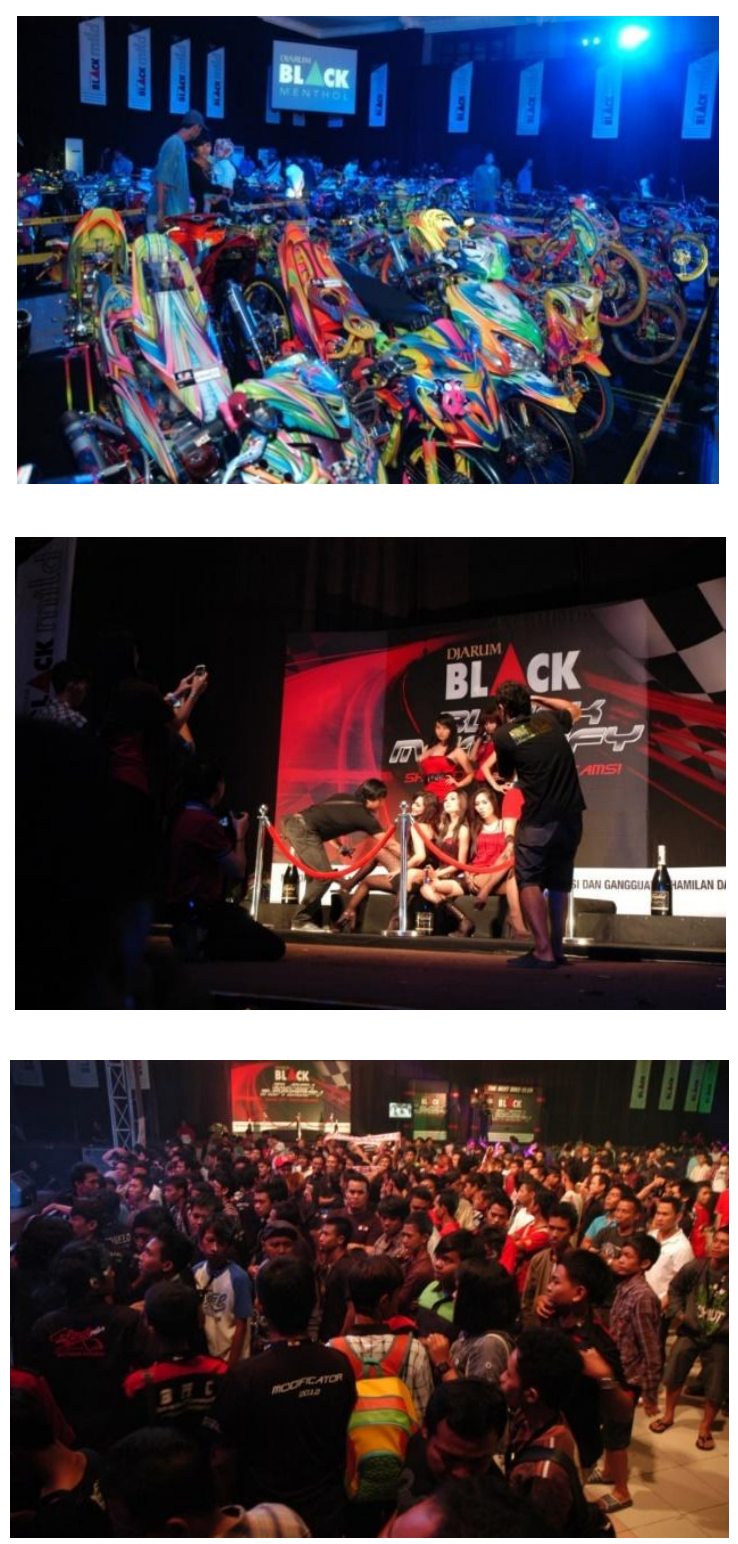

Figure 8. Motorcycles participating in modification contest in Djarum Black"Motodify"

Figure 9. Model Photographing Contest in Djarum Black "Motodify"

Figure 10. Audiences in Djarum Black "Motodify" event 


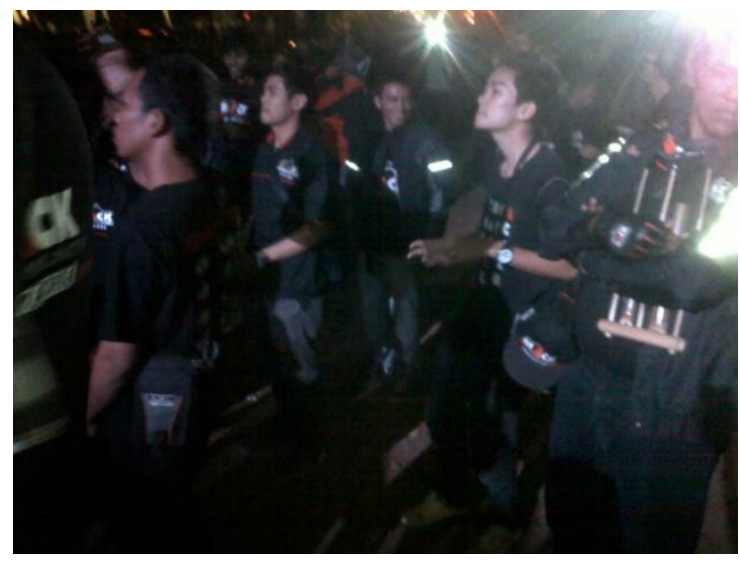

Figure 11. Djarum Black

Community in "Motodify" event

Media through abstract space greets the audience to make it the subject participating in urban lifestyle order later in the textual symbolic space. Abstract space carrying on the symbol of urban text can be called urban space. The terminology "urban space" itself is the production of intellectual practice through a verbal sign system, and articulated in science space. Urban space is present as the term representing lived space of contemporary human beings in urban areas (Lefebvre, 1991: 46). In this lived space, spatial practice occurs and continuously appropriating daily spatiality of urban human beings, in this case Djarum Black strategy targeting urban youths as the audience through a variety of its media channels published continuously.

The audiences are creative urban youths and represent the "typical” Djarum Black lifestyle character. Audiences are invited to identify themselves as active, creative, free, fashionable, open, and modern youths, and all of these are consistent with the meaning system of urban lifestyle constructed by Djarum Black. The "perfect" product of urban lifestyle results in Djarum Black community and consumers leading to hedonism of those having automotive modifying hobby, and then such the lifestyle is attempted to be imitated anywhere regardless the context of local culture. It often occurs in promotion strategy practice, in which publications in the form of visual media and even has been so close not only to its community but also ordinary people.

\section{CONCLUSION}

Using visual methodology with visual grammar can provide description and explain the structure of visual material in the form of code or sign related to the symbol of contemporary culture. All of ways elaborated in the method through this process are carried out in order to obtain the meaning expected by the author, that is, the meaning contained in visual branding of Djarum Black, constructing the 'typical' Djarum Black urban culture. 
Based on the results of the analysis "Visual Aesthetics Brand Djarum Black Urban Lifestyle in" performed at the Djarum Black Motodify there are some things that conclusion, among other things: First, the activities of this modification community to support the hobby, is not spared from the usual consumption behavior that are of value to the community therein. Use value is a function or benefit on commodities as well as the benefits of the activities carried out by the community. Usual consumption behavior such as buying a bike community, replacing the original parts with parts variation, touring, and others. This context explains the business community in supporting the activities of a hobby that faced the commodity that has been provided. Commodities ranging from Black Motor Community (BMC) as container dealer hobbies, activities offered in BMC, to goods and services consumed by that function or have benefits as a hobby for community support activities; Second, the value of the mark. Activity or hobby activities in supporting the community in addition to having benefits there are also markers. Signs in this context include visual branding Djarum Black and BMC.

Baudrillard develops his thoughts on the value of a sign or symbol. Value is usually a sign of status, prestige, expression, and others. This context is explained to the community's consumer behavior based on their meaning in the event Djarum Black Motodify.

Communities can express it by doing activities such as supporting an active hobby to follow the activities contained in the Black Motor Community, taking parts variation, and so forth. So the commodity purchased or consumed not only because of the benefits of a motorcycle as a means of transportation, but the motor as a symbol or a sign of status, prestige, and others; Third, the simulation. Simulation is the shifting meanings of value to the form of benefits or function into a value sign in the form of symbols. Simulation results in a space called simulacra, the space contains false realities shift results from use value to the value of the mark. Baudrillard likened to a map-making process that preceded the territory, so that visible is territorial (reality) are unclear origin. The simulation begins from abolishing the reference to reproduce the same form (sign). Emphasizing what Baudrillard (1983) simulation as a process to reproduce the same form in the form of object creation is simulative i.e. objects based on references that are not real or unclear origin. These context simulacra are a sense of satisfaction and pride that obtained when the community could use the motor modifications, expressed exceed the original function of the motor as a means of transportation.

In the discussion section in this article, it is actually what we experience daily, because many things are often related to visual media encountered so that we cannot see well a phenomenon occurring. When a promotion strategy through visual media and event has defeated the reality and has duplicated itself quickly and sporadically, the esthetics has taken over the world and removed reality. As a consequence, various 'lives' are reduced to 
codification of symbols and abstraction of the promotion strategy implementation. It is a challenge for us to attempt to go back and to see again what has happened, before go ahead.

\section{REFERENCES}

Baudrillard, Jean. 1983. Simulations. Semiotext(e), New York.

Black, James A. and Dean J. Champion. 1992. Method and Issues in Social Research, terjemahan E. Koswara, dkk, PT. Eresco, Jakarta.

Bogdan, R.C., dan Taylor, S.J. 1993. Dasar-dasar Penelitian Kualitatif, terjemahan oleh A. Khozin Afandi, Usaha Nasional, Surabaya.

Bourdieu, Pierre. 1991. Language and Symbolic Power, (John B. Thompson, ed.; transl. by. Gino Raymond and Matthew Adamson). Polity Press, Cambridge.

Foucault, Michel. 1977. Discipline and Punish. Penguin, London.

Kress, Gunther \& Theo van Leeuwen. 2006. Reading Images: The Grammar of Visual Design 2nd Edition. Routledge, London.

Leach, Neil. 1999. The Anaesthetics of Architecture. MIT Press, Massachusetts.

Lefebvre, Henri. 1991. The Production of Space, translated by Donald Nicholson - Smith, Blackwell, Oxford.

Lincoln, Yvonna S. and Egon Guba. 1985. Naturalistic Inquiry, Sage Publications Inc., California.

Miles, Matthew B. dan A. Michael Huberman. 2009. Analisis Data Kualitatif, terjemahan Tjetjep Rohendi Rohidi, Universitas Indonesia Press, Jakarta.

Patton, Michael Quinn. 2002. Qualitative Research \& Evaluation Methods. Sage Publications Inc., California.

Piliang, Amir Yasraf. 2003. Hipersemiotik: Tafsir Cultural Studies atas Matinya Makna. Jalasutra, Yogyakarta.

Rose, Gillian. 2001. Visual Methodologies: An Introduction to the Interpretation of Visual Methodologies. Sage Publications Ltd, London.

Rustan, Surianto. 2009. Layout Dasar dan Penerapannya. Gramedia, Jakarta.

Setijowati, Adi dkk (Ed). 2010. Sastra dan Budaya Urban dalam Kajian Lintas Media. Airlangga University Press, Surabaya.

Storey, John. 1993. An Introductory Guide to Cultural Theory and Popular Culture. University of Georgia Press, Athens.

Sturken, M. and Lisa Cartwright. 2001. Practices of Looking: An Introduction to Visual Culture. Oxford University Press, New York.

Sugiyono. 2007. Memahami Penelitian Kualitatif, CV. Alfabeta, Bandung. 